УДК 82I.I6І.I

ББК $83.3(2 \mathrm{Poc}=\mathrm{Pyc}) 6$
Н.П. АНЦИФЕРОВ И СОВРЕМЕННИКИ. ЗАПИСКИ ЛИТЕРАТУРНОГО СТАРАТЕЛЯ

(c) 2018 г. Е.Б. Белодубровский Независимый исследователь Санкт Петербург, Россия

Дата поступления статьи: 15 января 2018 г. Дата публикации: 25 июня 2018 г.

DOI: I0.22455/2500-4247-2018-3-2-309-329

Ключевые слова: Н.П. Анциферов, В.А. Мануйлов, А.А. Ахматова, переписка, воспоминания, рецензия.

Информация об авторе: Евгений Борисович Белодубровский - литературовед, археограф, член Союза ученых Петербурга, Союза писателей Санкт-Петербурга, Международного Мандельштамовского Общества (Москва), Французского сообщества набоковедов (Париж), г. Санкт-Петербург, Россия.

E-mail: profpnin@mail.ru

Для цитирования: Белодубровский Е.Б. Н.П. Анциферов и современники. Записки литературного старателя // Studia Litterarum. 2018. Т. 3, № 2. С. 309-329. DOI: I0.22455/2500-4247-20I8-3-2-309-329 


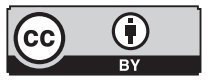

This is an open access article distributed under the Creative Commons Attribution 4.0 International (CC BY 4.0)

\section{ANTSYFEROV AND HIS CONTEMPORARIES. NOTES OF A LITERARY PROSPECTOR}

\author{
(C) 20I8. E.B. Belodubrovsky \\ Independent scholar, \\ St. Petersburg, Russia \\ Received: January I5, 2018 \\ Date of publication: June 25, 2018
}

Keywords: Nikolay Antsyferov, Viktor Manuilov, Anna Akhmatova, correspondence, memoir, review

Information about the author: Evgeny B. Belodubrovsky, independent scholar, literary critic, historian, member of the Union of Scientists and Union of Writers of St. Petersburg, International Mandelstam Society (Moscow), French Nabokov (Paris). Home address Prospekt kulturi I7, apt. Io, St. Petersburg 195274.

E-mail: profpnin@mail.ru

For citation: Belodubrovsky E.B. Antsyferov and his contemporaries. Notes of a Literary Prospector Studia Litterarum, 2018, vol. 3, no 2, pp. 309-329. (In Russ.)

DOI: $10.22455 / 2500-4247-2018-3-2-309-329$ 
Вступление. Статья написана в жанре воспоминаний. Ее автор - известный петербургский журналист, писатель, краевед, последним достижением которого стало открытие в 2о13 г. в Царском Селе под Петербургом новой улицы, получившей название «Анциферовская». Основной целью статьи является представление новых сведений о личных и профессиональных связях первооткрывателя «петербургского текста» русской литературы Н.П. Анциферова с известным литературоведом В.А. Мануйловым. Поводом для рассмотрения стала забытая рецензия Н.П. Анциферова на труд В.А. Мануйлова «Михаил Юрьевич Лермонтов» и переписка ученых. Н.П. Анциферов, автор главы «Лермонтов в Царском Селе» в книге «Лермонтовские места в окрестностях Ленинграда» (М., І940) как тонкий и знающий лермонтовед, дает точные оценки книге Мануйлова в своей рецензии, которую приводит автор статьи. Значительность впервые публикуемой переписки ученого с В.А. Мануйловым в том, что ее разрешением стала увидевшая свет весной I946 г. в Москве книга Анциферова «Пригороды Ленинграда». Автор связывает появление как книги Мануйлова о Лермонтове, так и книги Анциферова, с общей для обоих авторов больной темой восстановления после разрушительной войны литературных мест памяти, в которых были запечатлены жизнь и судьбы русских писателей и поэтов. Автор статьи приводит свои собственные яркие воспоминания о дружеских встречах с В.А. Мануйловым, во время которых постоянно упоминался Н.П. Анциферов, включившие в себя также новые сведения и предания о культурной жизни Ленинграда І970-х гг. Среди них знаменательные встречи в Пушкинском Доме, на заседаниях «Секции книги и графики» при петербургском «Обществе библиофилов», история подготовки знаменитой «Лермонтовской энциклопедии». 
20 октября 1945 г. в «Литературной газете» в Москве была напечатана под названием «Маленькие монографии» рецензия Николая Павловича Анциферова на издание в Пензе, в местном книгоиздательстве при газете «Сталинское знамя», двух небольших книжек: «Михаил Юрьевич Лермонтов» В. Мануйлова и «Иван Иванович Лажечников» В. Нечаевой. И если на сегодняшний день оба эти издания следует отнести к разряду раритетов, то их авторы, литературоведы Виктор Андроникович Мануйлов (1903-1987) и Вера Степановна Нечаева (I895-1979), оставили каждый в своей области наук весьма заметный след. Что же касается текста рецензии, то его, равно как и книги, тоже можно смело отнести к той же категории раритетов. Правда, есть еще один печатный источник, где мы находим прямое указание на эту рецензию (в числе еще нескольких «затерянных» оригинальных статей, заметок и коротких эссе Н.П. Анциферова І943-1944 гг.; например, об освобождении тургеневского Спасского-Лутовинова, Толстовской Ясной Поляны, о Киевской Руси, снятии блокады Ленинграда и др.)

Речь идет о полной поквартальной росписи содержания т. н. «Литературки» (и всех центральных газет), издававшейся «Книжной Палатой CCСР» в виде стандартных тетрадок-бюллетеней. Но и тут те же проблемы: местонахождение, их ветхость (слепая печать, серая бумага, и на скрепке), отчего они, невостребованные, годами пылятся на дальних полках биобиблиографических и справочных отделов библиотек, несмотря на высокий авторитет и статус издателя (не говоря уже о том, что не всякий из нас, как говорится, «знает туда дорогу»). Отсюда следует, что «новооткрытый» текст в принципе должен быть известен ученым, но я говорю слово «должен» с некоторой осторожностью, так как ни в одном из самых современных изданий и переизданий трудов Николая Павловича (и комментариев к ним) ссылки или даже намека на эту газетную публикацию я не обнаружил. А это обстоятельство, как известно, факт в нашем деле эвристического литературного поиска существеннейший.

В этой рецензии и, особенно, в той части, где говорится о книге Мануйлова (именно ей посвящена большая часть), Николай Павлович вновь и вновь видится не столько как краевед, сколько как толковый знаток биографии и творчества Лермонтова (точнее сказать, как лермонтовед). Пушкинистом Анциферов стал едва ли не с первого момента, как поселился в Царском. Но можно ли в полной мере осознать гений Пушкина, не обратившись к лире 
молодого Лермонтова, также неоднократно бывавшего в Царском Селе в разные годы своей короткой жизни? В подтверждение этой мысли я обращаю внимание к главе, под названием «Лермонтов в Царском Селе», принадлежащей Анциферову в книге «Лермонтовские места в окрестностях Ленинграда» (М., І940, серия «Путеводители государственного литературного музея»; он здесь один из трех авторов, ленинградских краеведов), в которой Николай Павлович едва ли не первым обнаружил все прежние названия улиц и прямые адреса домов Царского Села и окрест его - где Лермонтов живал будучи юнкером и где в зрелые годы останавливался на постой, с кем бродил и делился стихами, с кем просто видался, а с кем и нет! И вместе с тем - вкупе с накопленными знаниями биографии и творчества Лермонтова - Анциферов восстановил картины жизни и быта обитателей Царского Села, этого небольшого селения под Петербургом в пору пушкинского былого...

К выходу книги о Лермонтове Виктор Андроникович также был довольно широко известным и признанным лермонтоведом, как в научных кругах, так и у массового читателя... В І94I г., когда начало войны почти день в день совпало со столетием смерти Лермонтова, Мануйлову было поручено возглавить при издательском отделе Пушкинского Дома так называемую «Оборонную серию», где в числе первых были изданы массовым тиражом сразу две книги о Лермонтове...

Однако свой путь к Лермонтову Виктор Андроникович начинал как пушкинист (как, впрочем, и Анциферов). Его экзаменом на этот «чин» стала дипломная работа, посвященная поэме Пушкина «Граф Нулин». Во многом новаторская, пионерская, признанная оппонентами как настоящее исследование (не только самой поэмы, но эпохи ее создания), она открыла бывшему студенту-заочнику Бакинского университета дорогу - ближе к Пушкину - на берега Невы. То был г927 г. Работу Мануйлова «заметила» Анна Ахматова, сама только-только вступившая в ряды «племени пушкиноведов». И направила двадцатичетырехлетнего молодого ученого и поэта (есть рассказ, как В.А. Мануйлов ходил к Анне Андреевне с тетрадкой стихов) в помощь маститому пушкинисту Петру Елисеевичу Щеголеву, который вознамерился написать книгу о Лермонтове. Через год-полтора, весной 1929 г., такая книга была написана, и в ней, по рассказу Д.С. Лихачева, львиная доля текста и комментариев принадлежала Виктору Андрониковичу, что подтверждается отчасти и авторским предисловием: 
Лермонтов в жизни, Лермонтов - человек и поэт, как он рисуется в представлении современников, в официальных свидетельствах и документах, на фоне подлинных исторических материалов эпохи. Восстановить этот образ в воображении современного читателя - вот задача настоящей книги. Моим помощником в работе над этой книгой был В.А. Мануйлов: он принимал участие в отборе и распределении материала $[4$, с. 5].

И вскоре тот же Щеголев приглашает своего помощника к своей новой «лермонтовской» работе. На этот раз - написать совместный сценарий для художественной киноленты о поэте и его судьбе. Фильм был снят и даже имел успех (критика в первую очередь отмечала добротный сценарий; печальной судьбе этой картины посвящено много статей), а затем Щеголев привлекает Виктора Андрониковича к созданию оригинального словаря, получившего название «Путеводитель по Пушкину», где Мануйлову принадлежат две классические статьи: «Анчар» и «Граф Нулин». «А propos» замечу одну странность - отсутствие в этом воистину замечательном «щеголевском» издании не только статьи «Лермонтов», но даже упоминания его имени, как, впрочем и статьи «Анциферов» в будущей «Лермонтовской энциклопедии» Мануйлова (которая в науке существует не иначе как «мануйловская»), кроме глухого указания на главу Анциферова из той «путеводной» московской книжки о лермонтовских местах в Ленинграде и его окрестностях г940 года издания.

Возвращаюсь к анциферовской рецензии.

\section{Маленькие монографии}

Пензенское издательство поставило перед собою задачу осветить роль своего края в жизни и творчестве наших классиков. Решение этой задачи содействует не только интересам литературоведения, но и краеведения. М.И. Калинин писал: «Все мы очень много говорим о воспитании патриотизма. Но ведь это воспитание начинается с углубленного познания своей родины. Следовательно, и по этим соображениям надо изучать местную географию». Той же высокой цели содействует и изучение местной областной литературы. Оба автора рецензируемых книжек подошли совершенно с разных точек зрения к стоящей перед ними задаче. В. Мануйлов в книжке, посвященной 
Лермонтову, не отделил описания жизненного пути поэта от его творческого пути. Основные проблемы, связанные с изучением Лермонтова, в той или иной мере затронуты Мануйловым в его сжатом, но насыщенном материалом очерке. Первая, вступительная глава посвящена той роли, которую сыграла поэзия Лермонтова в годы Великой Отечественной войны, когда действительно «стих» поэта «звучал, как колокол на башне вечевой во дни торжеств и бед народных». Приведенные автором отрывки из стихотворений поэта обрели новую жизнь в годы, решавшие судьбу нашей родины. К сожалению, В. Мануйлов среди фактов, характеризующих отношение к Лермонтову защитников советского отечества, не отметил героического партизанского отряда, бившегося с гитлеровцами на Кавказе, того отряда, который носил имя Лермонтова.

В дальнейшем автор из года в год прослеживает жизненный и творческий путь русского гения, ставшего жертвой мрачного царствования Николая I. Вольнолюбивый дух Лермонтова, его глубокий патриотизм, его страстное стремление к «действованию», к борьбе хорошо обрисованы В. Мануйловым, привлекшим мало известный материал.

В заключительной главе автор привел данные, характеризующие влияние Лермонтова на национальные литературы народов СССР, а также отрывки о нем А.M. Горького и С.М. Кирова. Приведены также примеры цитирования Лермонтова В.И. Лениным.

При предельно сжатом изложении трудно избежать некоторых неясностей. Так, например, характеризуя Московский Университет на рубеже 20-30-х годов прошлого века, автор пишет: «Преподавание в Университете было поставлено очень плохо». Это слишком категоричное утверждение противоречит действительности. Достаточно отметить лекции профессора М.Г. Павлова. Другой пример: образ бедного чиновника Красинского («Княгиня Лиговская»), безоговорочно включенного В. Мануйловым в традицию гоголевских чиновников «Петербургских повестей». Между тем как Красинский Лермонтова, в отличие от робкого Акакия Акакиевича, полон гордости и независимости. Здесь Лермонтовым замечена другая, своя линия. Мало сказано также о Лермонтове как художнике. Поэт был не обычным «любителем-рисовальщиком», в его зарисовках, в особенности в его ландшафтах, виден большой талант подлинного живописца. Эти замечания нисколько не умаляют больших достоинств книжки В. Мануйлова, чрезвычайно содержа- 
тельной и умело написанной. Задача показать общенациональное значение Лермонтова автором разрешена достаточно основательно. Как же обстоит разрешение другой задачи, как выяснена связь Лермонтова с Пензенским краем? В этом отношении хотелось бы встретить в книжке В. Мануйлова больше материала. Можно было бы подробнее описать движение Пугачева близ Тархан, рассказы о котором оставили след в душе Лермонтова и получили отражение в его «Вадиме». Следовало бы привести описание Тархан в стихотворении «Как часто пестрою толпою окружен...». Все же автор привел много ценного, характеризующего жизнь Лермонтова в Тарханах.

Совершенно иначе подошла В. Нечаева в своей книжке «Иван Иванович Лажечников» к решению задачи, поставленной областным издательством. Общую характеристику этого замечательного представителя жанра исторического романа В. Нечаева ограничила одной, но весьма существенной проблемой. Она оставила в стороне вопрос о месте романов Лажечникова в развитии русского исторического романа, не затронула вопрос о влиянии Вальтера Скотта на русского писателя, воздержалась от анализа художественных образов. В. Нечаеву интересует проблема, делающая Лажечникова писателем, близким современному читателю. В книжке прослеживается тема, объединяющая сразу три романа: «Последний Новик» (I83I), «Ледяной дом» (I835) и «Басурман» (1838). Эта тема - создание могучего русского государства. Таким образом, автор рассматривает романы Лажечникова как трилогию. Книжка В. Нечаевой распадается на две части. В первой дана биография Лажечникова, во второй - характеристика его творчества. Интересен материал, характеризующий романиста в Отечественную войну г8г2 года. Особое внимание уделено в обеих частях книги связям Лажечникова с его земляком В. Белинским. Достоинством работы В. Нечаевой является использование неопубликованных материалов, как Центрального литературного архива, так и Пензенского областного архива» ${ }^{ }$.

Как видите, Николай Павлович назвал свою рецензию «Маленькие монографии» и тем самым поднял статус этих скромных научно-популярных книжек до статуса научного издания, тогда как они, казалось бы, предназначены единственно для краеведов или музейных работников местного 
масштаба. Можно согласиться с рецензентом, что упущением автора было не упомянуть о партизанском отряде, носящем имя Лермонтова и бьющем немца на Кавказе; не совсем верно было и его (Мануйлова) слишком поспешное мнение автора о якобы «плохой» постановке образования в Московском университете; что же касается трактовки сложного образа Красинского, прямо скажем, «туманного» и для самого Лермонтова, то ученые, теряясь в догадках, до сих пор ломают копья в поисках истины. Не совсем справедлива и «претензия» рецензента к Мануйлову по поводу недостаточности сведений о Тарханах и о таланте Лермонтова-живописца. Скорее всего, Виктор Андроникович просто был связан заданным объемом. С другой стороны, можно подивиться, как Анциферову удалось, обращаясь за «поддержкой» то к Ленину, то к Кирову, к Горькому или к Калинину, избежать ссылки на «иосиф-виссарионовича»; зато каким теплом «дышит» слово Анциферова о постоянном «страстном стремлении Лермонтова к “действованию”», отправляя этим закавыченным термином (нас, и читателя, и автора книги) к бессмертным «Литературным мечтаниям» В.Г. Белинского из далекого I834 г.: «Жизнь есть действование, а действование есть борьба».

Читая и перечитывая этот газетный текст, я вдруг увидел множество будирующих мою душу сюжетов и поворотов, потянувших меня к далекому прошлому. И я с жадностью неимоверной бросился к своим старым записям, дневничкам и тетрадкам той неповторимой поры моего «шестидесятничества». Прошлый опыт старателя подсказывал мне, что я нахожусь на пороге какого-то нового знания об этих двух ученых - a, может быть, и о Лермонтове...

Но дальше - больше, после своего лоскутного домашнего архива я полез с головой в личные фонды обоих ученых, благо они почти полностью обработаны и вполне доступны посвященным.

И «пошла писать губерния»!

Но все по порядку: дневники и записи. Из этих записей я выбрал две наиболее интересные; в них описаны встречи с В.А. Мануйловым, отмеченные упоминанием (присутствием) в разговоре Николая Павловича.

Обе - в разное время, но в одном и том же Пушкинском Доме...

197І г. Февраль. Наш разговор в буфете с В.А. Мануйловым о поэте Михаиле Кузмине и о Лермонтове. В ту пору в Пушкинском Доме как-то неожиданно (и даже странно) открыли на первом этаже перед входом на 
черную лестницу такой скромный, почти походный буфет с пирожками, чаем и даже с чем-то более существенным. Но главным здесь был пузатый титан с кипятком. Буфет работал два раза в неделю (кажется, с I2 до I6 часов и только в «присутственные» дни - понедельник и четверг). И своим нехитрым репертуаром был предназначен для краткого перекуса штатных сотрудников. Случайные люди здесь были исключены. Кроме, пожалуй, читателей Рукописного отдела Института. В пристеночке буфета этот счастливец мог постоять в одной очереди за чаем, кипятком, а то и оказаться за одним столом с кем-нибудь из «небожителей» и даже перекинуться краткой беседой. Так и произошло: вот я стою в такой очереди, и впереди меня Виктор Андроникович Мануйлов в тюбетейке, человек мне давно знакомый и весьма-весьма почитаемый всем ученым миром. И - по моей инициативе - у нас завязался разговор. Дело в том, что накануне я присутствовал на очередном заседании «Секции книги и графики» при нашем «Обществе библиофилов», где Виктор Андроникович, по известному выражению Анны Андреевны Ахматовой, «торжественно и трудно» докладывал собравшимся пытливым книгочеям о начавшейся в Пушкинском Доме подготовке издания персональной «Лермонтовской энциклопедии». В конце доклада пошли вопросы из зала, посыпались имена современников Лермонтова, его друзей и недругов... Виктор Андроникович терпеливо записывал...

Леонид Ильич Борисов, ленинградский писатель и завзятый библиофил, приглашенный на наше заседание самим Виктором Андрониковичем, неожиданно для всех встал со своего места, двинулся к трибуне и громогласно потребовал от Виктора Андрониковича немедля исключить из энциклопедии имя Михаила Кузмина - автора самого дерзкого лживого стихотворения о Лермонтове, напрочь искажающего его светлый образ. И тут же предъявил собравшимся вырезку из юбилейного номера «Биржевки» за июль I9I6 г. с текстом этого несчастного опуса... Кое-кто из знатоков и сверстников Борисова тут же с ним согласился. Но Виктор Андроникович мягко оборвал гостя и поведал собравшимся о том, что Михаил Алексеевич Кузмин, замечательный наш поэт, вскоре «исправился». И написал новое стихотворение. С тем же названием «Лермонтову», где образу поэта отдано должное, что и требовалось доказать...

Не успел Борисов что-то прокричать свое - мол, это второе стихотворение было напечатано позже и так далее, как Виктор Андроникович, 
спустившись с трибуны в залу, своим тихим голосом прочел это стихотворение наизусть, и случился триумф.

И вот в той очереди за кипятком я спросил, с какой стати Борисов так ополчился на Кузмина, зачем, мол, причина какая... Виктор Андроникович ответил, что ему, мол, тоже досадно и даже совестно за те строки Кузмина, которые можно считать несправедливыми. Но, когда речь идет о большом русском поэте, каким был Михаил Алексеевич, надо смириться. И добавил, что, мол, вы же знаете тоже, что и Лермонтов был неприятным собеседником и среди друзей и мог так поддеть товарища... И повторил теми же словами: но ведь речь идет о большом русском поэте. И вдруг доверительно так посмотрел на меня и сказал: вот Николай Павлович Анциферов считал, что как поэт Лермонтов выше Пушкина, только, добавлял он - слишком короток был его век... И что для человека всегда нужнее Лермонтов, он поэт для трудной минуты, а таких минут у Николая Павловича было по горло...

Октябрь - ноябрь. I974 г. Я работал тогда на студии телевидения и писал как внештатный автор короткие сценарии о Петербурге и поэтах для литературной редакции. И вот к очередному юбилею Лермонтова в поисках чего-нибудь нового, подзабытого, я отправился в газетный зал Публички полистать летучие петроградские газеты за июнь - июль I9I6 г. И действительно, в газете «Петроградский голос» мне попалась заметка об открывшейся лермонтовской выставке в Николаевском кавалерийском училище. Читаю: «В одной из витрин находится письмо Лермонтова к своей кузине Марии Львовне Дурново, урожденной Симанской, написанное кровью [курсив наш. - E.Б.]. Оно помечено І836 годом. Письмо это до сих пор еще не опубликовано и представляет большой интерес. Содержание его следующее: «Дорогая кузина, я польщен вашим приглашением и конечно им воспользуюсь. К моему величайшему огорчению, мой двоюродный брат Столыпин умер, и я вас посещу через несколько часов, как только исполню свой последний печальный долг. Ваш на весь вечер и на всю мою жизнь. М. Л.».

Ничего себе! И вот с этим «кровавым» открытием я срочно отправился за комментарием «из первых уст» к Виктору Андрониковичу - в «Кабинет М.Ю. Лермонтова», которым он «правил». Мануйлов, прослушав мой восторженный рассказ, спокойно заметил, что это письмо, действительно написанное кровью, вместе со всеми экспонатами той выставки в І9г8 г. было передано из Николаевского училища благодаря усилиям ака- 
демика Нестора Котляревского в Академию наук (в том числе даже портрет сей кузины, копию которого Виктор Андроникович обещал найти у себя в «Кабинете...» и дать мне для сюжета). Но к своему рассказу он добавил одну подробность, то есть один малоизвестный случай, произошедший на той выставке в Николаевском училище, в котором был «замешан» Николай Павлович Анциферов в пору его (Анциферова) служения учителем истории и литературы в Женской гимназии некой полковничихи Зварской. То есть в самом конце выездного внеклассного урока, посвященного судьбе Лермонтова, Николай Павлович обнаружил пропажу одной девицы. Затем со второго этажа был услышан звон стекла и крик. Дежурные офицеры бросились наверх и увидели, как эта девица тайком пыталась вскрыть витрину, где лежало то самое письмо, дабы убедиться, что на нем действительно кровь ею обожаемого поэта. И даже слегка заболела... А как такой «случай» не попал в газеты, спросил я Виктора Андрониковича. Ответ был неожиданный: мол, ничего странного, время было военное, напряженное, и это происшествие бросало тень легкомыслия на столь высокое учреждение. И добавил: сначала этот эпизод сохранил в своей памяти Николай Павлович, затем я, а теперь - вы...

Да, чутье чутьем, опыт опытом, но сколько бы еще пролежали в моем домашнем архиве эти мои старательские лоскутные записки об Анциферове и Мануйлове. И вот - пригодились...

Остается назвать источник, где для меня лично «томился в безвестности» этот самый текст Николая Павловича. Некоторое время назад один мой старший друг и коллега, архивист из Бремена, просил меня съездить в архив на Шпалерную. И заглянуть там в личный фонд Мануйлова на предмет наличия в нем «следов» одной имярек поэтессы, с которой Виктор Андроникович был знаком в годы своей учебы в Бакинском университете. И где они оба посещали поэтическую студию Вячеслава Иванова².

Но время было летнее, каникулярное, и архив работал реже, чем в обычные дни, да и друг мой меня не слишком торопил: архив - дело серьезное. И тогда я решил «для полноты картины» на всякий случай глянуть на этот предмет со стороны библиографической. Это значит пойти в Пушкинский Дом и там пролистать знакомый мне с давних пор наиболее полный

2 Моя личная благодарность господину Г.Г. Суперфину, указавшему на место хранения архива Виктора Андрониковича. 
«Послужной список профессора Виктора Андрониковича Мануйлова». И как это иногда случается в нашей цеховой эвристической практике, ищешь одно - находишь другое (конечно, нужного имени в нем не оказалось и близко - к печали моего заветного друга)... И вот «нате вам»: 1945 г., октябрь, «Лит. газета», Анциферов, Мануйлов, Нечаева. Но и тут нам не обойтись без слова «редкость», ибо эта скромная книжечка на скрепке в сероватой картонной обложке в 40 и чуть более страничек - результат работы большого коллектива ученых-музейщиков и лермонтоведов из Ленинграда, Москвы, Пятигорска, Краснодара и самого лермонтовского Темрюка. Тираж - 50. Не менее уникальна обложка, которую по праву нужно считать первым номером всего этого весьма внушительного прижизненного списка трудов В.А. Мануйлова. На ней, как говорится, «в полный рост» и был напечатан (скорее, выставлен как картина) экслибрис личной библиотеки Виктора Андрониковича: строгий, изящный, летящий по волнам, одинокий, белеющий вдали парус, нарисованный художником одним росчерком, без отрыва пера от бумаги. И под ним - подпись VIKTORIS.

Тут есть история (это опять же из моих тетрадочек I97I-I972 гг.), которой я был свидетелем... Как я уже упоминал, в «Обществе библиофилов» при Доме книги существовала так называемая «Секция книги и графики», где тон задавали художники-экслибрисисты. И вот «вижу», как на одном из заседаний секции в апреле I97I г. нам был представлен этот «Парус» в присутствии самого В.А. Мануйлова. Вот они, те самые «странные сближенья»!

Теперь - архивы. В первую очередь - Шпалерная (по наказу друга), личный фонд В.А. Мануйлова. Разобрана пока только его переписка. Принесли опись! Листок пользователя - чист. И вот - праздник. Открытка Мануйлова Анциферову из Ленинграда в Москву, июнь I944 г. И целых два ответных письма Анциферова Мануйлову из Москвы в Ленинград, первое от II июня I944 г. и второе - август того же года...

Заказ - только на следующей неделе.

Бегу через мосты в Публичку - смотрю описи личного фонда Николая Павловича. Имени Мануйлова - нет. Ни его писем, ни статей, ни заметок.

Однако в описи (о, счастье!) нашлись телеграмма, карандашная записка и одно письмо (с конвертом) Анциферова к жене Софье Гарелиной из Ленинграда в Москву, отправленные им в июне г944 г. 
То есть это те заповедные летние победные дни, когда Николай Павлович впервые побывал в Пушкинском Доме после снятия блокады и посетил свое родное пепелище - Царское Село. Их адресат - самый близкий и самый доверительный Николаю Павловичу человек, с которым он торопится поделиться первыми впечатлениями. Вскоре передо мной лежали два смятых полустертых листка серой бумаги с текстами, написанными торопливым карандашом. Каждая строка и для нас, посвященных, - сердцем щемит, а надеждой теплится... Дата на штампе конверта - 24 июня 1944 г.!

\section{Моя дорогая Сонюшка,}

ты уже вероятно получила мою срочную телеграмму, и как срочную, посланную через Пушкинский дом. Сегодня пишу с оказией, письмо будет опущено завтра в Москве, надеюсь, что ты получишь его до моего возвращения.

Летели мы хорошо. Были ухабы, но в общем самолет шел хорошо. Земля под нами - веселая, зеленая, пространная с голубыми глазами озер, с лиловатыми пятнами пашни. Ленинград произвел глубокое впечатление. Это неверно что у него нет глаз, что он ослеп - как это писали в газетах. Мне он показался - (я пишу о его панораме, а не о людях) уставшим от страданий, с опущенными веками, побледневшим. (Серые здания, серые, а не «светлые» иглы, серый купол Исаакия, и под серым небом серая - металлическая Нева) Людей мало, звуков мало. Город «под сурдинкой». Приглушенный и в красках и в звуках. В Белые ночи, когда так был характерен отблеск зорь в тысячах глаз-окон - теперь не те - глаза закрылись. Изумительным благородством, необычным спокойствием веет от лика этого непобедимого города. Я все <нрзб.> с сердцем, которое сжимается любовью и печалью. Пострадал он сильно. Всюду видны раны - легкие от многочисленных осколков, тяжелые от снарядов и наконец руины от фугасок, местами прикрытые декоративными занавесями.

Утром вчера был на кладбище. Трамвай теперь к Смоленскому не ходит - от Среднего шел пешком. Первое впечатление все будило надежды. Среди бурно разросшейся зелени - много крестов. Но вскоре я заметил, что среди этих крестов нет ни одного деревянного. Они все пошли на топливо. Свои могилы я находил по деревянному зданию сторожки, но и оно исчезло. Все же я нашел могилу Павлиньки, его каменный крест уцелел. По нему 
я определил могилу Татьяны Николаевны, на месте креста вырос вьющийся лопух, поднявшийся над другими травами. Могилу Таточки, которая отстояла отдаленная 45-ю могилами, я определить не мог, так как все деформировано, та, что наиболее подходит, укреплена маленьким металлическим крестом, вставлена в яму, образовавшуюся от падения большого креста, и нет на холме каменной облицовки. Я заказал для Таточки небольшой металлический крест. В понедельник буду еще раз. Крест стоит только всего лишь I50 рублей. И на могиле Блока нет креста. Этот новый крест я ставлю с мыслью о Светике. Сегодня чудесное утро. Завтра или послезавтра надеюсь быть в Пушкинез.

Вернемся к переписке Мануйлова и Анциферова. Как видим, она знаменательна для нашего очерка по датам, ибо полностью совпадает с тем первым приездом Николая Павловича в Ленинград (см. записку Анциферова жене). Конкретный сюжет этой краткой переписки и прост, и величественен. Ибо ее венцом - ее разрешением, была увидевшая свет весной 1946 г. в Москве книга Николая Павловича Анциферова «Пригороды Ленинграда. Города Пушкин, Павловск, Петродворец» - лучшая, на мой взгляд, и как исследование историка, и как знатока русской литературной классики, и как краеведа академической высоты. От зарождения самой идеи книги до ее полного триумфального воплощения.

Она написана Анциферовым (до войны постоянным жителем Царского и окрест, которому был знаком здесь каждый уголок и пригорок) спустя всего лишь полтора года (или чуть больше, когда Николай Павлович впервые был здесь в июне г944 г. и содрогнулся увиденным; первым, как известно, в конце января того же года сюда и прямо на пятках убегающих фрицев прибыл на военном автомобиле Виктор Андроникович Мануйлов вместе с Ольгой Берггольц, Лазарем Маграчевым и еще каким-то чиновником от Смольного), когда следы оккупации и раны, нанесенные врагом этим городам, были еще налицо. Эта книга - преодоление. Все в ней дышит не столько осуждением преступных деяний чужеземцев, сколько светлым, уверенным оптимизмом автора, предвидевшего восстановление. 
Н. П. Анциферов - В. А. Мануйлову (Из Москвы в Ленинград). II июня I944 г.

Дорогой Виктор Андроникович!

Простите, что задержал ответ: я все еще надеялся как-нибудь устроить мой приезд и таким образом принять участие в работе над сборником о пригородных дворцах и парках. Но мне здесь все сроки спутали. Диссертация назначена на конец июля, а сдача плана, из-за которого я так торопился, назначена на конец августа (как глупо, что я не задержался в Ленинграде). До сдачи плана меня, конечно, не пустят. Оказать же давление на Музей через высшие органы я не хочу, так как Музей, где я работаю с 1936 года, всегда относился ко мне хорошо. Как ни грустно, но мне не удастся принять участие в работе столь для меня интересной во всех отношениях. Я не могу найти ни имени, ни адреса Соколова. Сообщите мне их, а пока покажите ему содержание этого письма. С Иг. Эм. Грабарем мне не удалось повидаться. В летнее время это особенно трудно. Все же надеюсь в ближайшие дни его увидеть, тогда напишу Вам. Остаток свободного времени посвящаю работе над окрестностями, но, увы, вполне сознаю, что в изд-ве нашего Музея мой труд не поймут и не оценят. Сердечный привет Влад. Мих. и Матв. Матв.

Искренне благодарный Вам - Н. Анциферов

В.А. Мануйлов - Н.П. Анциферову.

(Из Ленинграда в Москву).

Ленинград, 23 июня г944 г.

Дорогой Николай Павлович!

Очень досадую и просто утешиться не могу, что Вы уехали, не послушавши моего совета и не договорившись ни о чем с Соколовым в Горкоме. Это была очень большая ошибка. Тут создалось впечатление, что Вы в работе над пригородами не заинтересованы, а Ваше, по мнению Ю.П. Францева, было бы весьма желательным. Помочь делу еще можно. Необходимо приехать в Ленинград и обо всем договориться. Мне кажется, что это следует сделать немедленно, до защиты диссертации. Иначе Вы упустите благоприятный момент.

Что с Пушкинским Музеем в доме Пушкина5. 
Н.П. Анциферов - В. А. Мануйлову.

(Из Москвы в Ленинград)

II августа I944 г.

Ваше письмо вновь подняло во мне «несбыточные мечты». Я решил же сразу ответить Вам, чтобы еще раз все обдумать. Вывод один - мне сейчас не под силу взять на себя эту работу и сломить намеченную здесь жизнь и работу. Я не хочу, чтобы у Вас осталось впечатление, что в Ленинграде я не должным образом отнесся к Вашему совету. Я считаю и теперь, что Вы правы, убеждая меня в том, что я должен принять участие в работе над пригородами. И все же мое решение не выполнимо. Я устал. Что-то должно преодолеть внутри - и нет сил. Еще раз я во всей полноте ощутил свою кровную связь с любимым городом, и вместе с тем, отойдя опять от него, не могу не сознаться, что он для меня лично уже кладбище, которое я должен посещать, но на котором жить не в силах. Только вчера говорил с директором Пушкинского музея и с одним из оставшихся работников Истор. Музея. Последний по-прежнему утверждает, что они не пустят обратно музей. А директор мне разъяснил, что существует специальное постановление Совнаркома о передаче их помещения в Истор. Музее, и отменить его решение может только Совнарком. Буду Вас держать в курсе этой борьбы. Привет. Ваш - Н. Анциферов 6 .

Интересно, кто кроме Николая Павловича был в составе так называемой «Комиссии по восстановлению...» (председателем от Совнаркома был академик А.Н. Толстой) от Литературного музея и ИМЛИ?

О Кресте на могиле А. Блока на Смоленском... Еще немного времени - и могилу перенесут... А зачем, в чем целесообразность, ведь могилу Некрасова не стронули...

Замечу лишь, что эта могила была особо дорога Николаю Павловичу, ибо (по личным воспоминаниям Елены Витальевны Бианки, дочери В.В. Бианки) он и Н.П. - оба присутствовали лично на похоронах Блока.

Отказ Николая Павловича поехать в Смольный для участия в совещании, в чем искренне не мог «утешиться» Виктор Андроникович, связано не столько с потрясением и душевными муками от посещения города и дорогих могил, сколько просто с нежеланием лишний раз общаться с партий- 
ными чиновниками; в Москве он живет полной столичной жизнью, готовится к защите диссертации (кстати, «Литературная газета» несколько раз терпеливо, с переменой сроков и дат и упоминанием имен оппонентов и так далее публиковала в особом разделе о готовящейся защите Н.П. Анциферова с указанием темы), а в Ленинграде так называемый «Большой дом» не дремлет, мало ли что... Да и времени всего неделя с I7 по 24 июня, а надо, кроме основной задачи поездки, повидать Лозинских, Татьяну Борисовну, Толстых, внука Михаила... Это важнее.

Какой же духовной силой и Верой в свою Миссию на Земле обладал этот отнюдь не молодой человек, испытавший бремя зла и лагерной пыли ГУЛАГа, если он все-таки отозвался на призыв своего друга и соратника В.А. Мануйлова, а также других коллег - краеведов и ученых-реставраторов Ленинграда (многие из которых были его учениками) и составил таки эту (великую, повторяю) книгу, для чего ему пришлось вновь и вновь возвращаться на родное пепелище... И с еще большей тревогой пережить боль утрат и потрясений...

Ибо жизнь - это преодоление... 9 июня І946 г. Николай Павлович присутствовал (гостем из Москвы) в родном Царском Селе на открытии «Выставки по восстановлению..». От имени ленинградских ученых всех приветствовал Виктор Андроникович Мануйлов. Среди поэтов на трибуне - Анна Андреевна Ахматова...

Воистину «non multa, sed multum» (немного, но многое). 


\section{Studia Litterarum /20I8 том 3, № 2}

\section{Список литературы}

I Анциферов Н.П. Лермонтовские места в окрестностях Ленинграда // По лермонтовским местам. М.: Гослитмузей, І940. С. го2-гіо.

2 Анциферов Н.П. Пригороды Ленинграда: города Пушкин, Павловск, Петродворец. М.: Гослитмузей, І946. ІІ2 с.

3 Путеводитель по Пушкину / под редакцией П.Н. Сакулина, П.Е. Щеголева, Б.В. Томашевского, М.А. Цявловского и Д.П. Якубовича. М.; Л., І93І. 399 с.

4 Щеголев П.Е. Книга о Лермонтове. Л.: Прибой, І929. Вып. І. 328 с. 
Мемуары / Е.Б. Белодубровский

\section{References}

I Antsiferov N.P. Lermontovskie mesta v okrestnostiakh Leningrada [Lermontov places in the outskirts of Leningrad]. Po lermontovskim mestam [By Lermontov places]. Moscow, Goslitmuzei Publ., I940, pp. I02-IIO. (In Russ.)

2 Antsiferov N.P. Prigorody Leningrada: goroda Pushkin, Pavlovsk, Petrodvorets [Leningrad suburbs: towns Pushkin, Pavlovsk, Petrodvoretz]. Moscow, Goslitmuzei Publ., I946. II2 p. (In Russ.)

3 Putevoditel' po Pushkinu [Guide to Pushkin], eds. P.N. Sakulin, P.E. Shchegolev, B.V. Tomashevsky, M.A. Tsiavlovsky and D.P. Iakubovich. Moscow, Leningrad, I93I. 399 p. (In Russ.)

4 Shchegolev P.E. Kniga o Lermontove. [A Book about Lermontov]. Leningrad, Priboi Publ., I929. Issue I. 328 p. (In Russ.) 